\title{
Hubungan Jenis Kelamin dan Usia Anak Satu Tahun Sampai Lima Tahun dengan Kejadian Infeksi Saluran Pernapasan Akut (ISPA)
}

\author{
Azri Iskandar, Suganda Tanuwijaya, Lelly Yuniarti \\ Universitas Islam Bandung
}

\begin{abstract}
Abstrak
Infeksi saluran pernapasan akut (ISPA) merupakan penyebab mortalitas utama pada penyakit menular di dunia. Hampir empat juta orang meninggal diakibatkan ISPA di dunia, angka ini terutama terjadi pada bayi dan anak. Sekitar $5 \%$ anak di bawah 5 tahun terkena ISPA di Indonesia. Jenis kelamin laki-laki, usia di bawah 5 tahun, dan riwayat berat badan lahir rendah (BBLR) merupakan faktor host yang dapat mengakibatkan insidensi ISPA cukup tinggi. Tujuan penelitian ini untuk menganalisis hubungan jenis kelamin, usia, dan riwayat BBLR dengan kejadian ISPA pada anak usia 1-5 tahun. Penelitian ini menggunakan studi observasional analitik dengan rancangan penelitian cross sectional, data diambil dalam satu waktu. Variabel bebas dihubungkan dengan variabel terikat dengan analisis statistik uji chi-kuadrat. Data diperoleh dari kuesioner yang ditanyakan kepada orangtua pasien. Penelitian ini dilakukan di Rumah Sakit Umum Nurhayati Kabupaten Garut periode 1 April-14 Juni 2014. Hasil penelitian ini menunjukkan bahwa $58 \%$ anak laki-laki menderita ISPA $(\mathrm{p}=0,002)$ dan laki-laki lebih berisiko terkena ISPA 1,839 kali dibandingkan dengan perempuan. Berdasarkan usia, $58 \%$ anak berusia $1-3$ tahun menderita ISPA $(\mathrm{p}=0,003)$ dan anak usia 1-3 tahun lebih berisiko 1,77 kali dibanding dengan anak usia $3-5$ tahun. Berdasarkan berat badan lahir, 66 dari 144 (47,1\%) anak dengan berat badan lahir normal menderita ISPA (p=0,910). Simpulan, terdapat hubungan jenis kelamin dan usia dengan kejadian ISPA dan tidak terdapat hubungan antara riwayat BBLR dan kejadian ISPA pada anak usia $1-5$ tahun.
\end{abstract}

Kata kunci: Anak usia 1-5 tahun, BBLR, ISPA, jenis kelamin, usia

\section{The Correlation of Sex and One to Five Years of Age with Acute Respiratory Infection (ARI)}

\begin{abstract}
Acute respiratory infection (ARI) is a major cause of mortality in infectious diseases in the world. About four million people around the world died caused by ARI, especially common in infants and children. About $5 \%$ of children under 5 years suffered from ARI in Indonesia. Gender male, under 5 years old and a history of low birth weight (LBW) are a host factor that can lead to a high incidence of ARI. Therefore the purpose of this study was to analyze the relationship between gender, age and history of LBW with ARI incidence in children aged 1-5 years old. This study used an analytical method with a cross-sectional study design, where the data were taken at a time. The independent variable correlating with the dependent variable in the statistical analysis chi square test. The data were taken from a questionnaire that were asked to parents of patients aged 1-5 years. This study was conducted in the General Hospital Nurhayati Garut in 1 April to 14 June 2014. These results showed that $58 \%$ male children suffered from ARI ( $\mathrm{p}=0.002)$ and male were more at risk for ARI 1.839 times compared to female. Based on the age, $58 \%$ children aged $1-3$ years suffered from ARI $(\mathrm{p}=0.003)$ and children aged $1-3$ years were more at risk for ARI 1.77 times compared to children aged 3-5 years. Based on birth weight, 66 of $144(47.1 \%)$ children had normal birth weight suffered from ARI $(\mathrm{p}=0.910)$. In conclusions, there are a relationship between sex, age and the incidence of ARI and there is no relationship between a history of LBW and ARI incidence in children aged 1-5 years.
\end{abstract}

Key words: ARI, children 1-5 years, gender, LBW

Korespondensi: lelly.yuniarti@gmail.com 


\section{Pendahuluan}

Infeksi saluran pernapasan akut (ISPA) adalah gangguan sistem pernapasan yang paling sering. Faktor penyebab yang memengaruhi ISPA pada anak terutama adalah faktor agen seperti beberapa virus yaitu rhinovirus, respiratory syncytial virus (RSV), parainfluenza virus, severe acute respiratory syndrome corona virus (SARS-CoV), dan virus influenza, atau dapat juga diakibatkan oleh bakteri, jamur, dan protozoa. Faktor host juga memengaruhi kejadian penyakit ISPA beberapa di antaranya jenis kelamin, usia, status gizi, riwayat BBLR, status pemberian ASI (air susu ibu) eksklusif, status imunisasi, dan penyakit lain. Faktor terakhir yang memengaruhi kejadian penyakit ISPA adalah faktor lingkungan seperti polusi udara, status ekonomi, dan juga pendidikan orangtua. ${ }^{1}$

World Health Organization (WHO) pada tahun 2007 menyatakan bahwa hampir empat juta orang di dunia meninggal akibat ISPA dengan mortalitas sangat tinggi pada bayi, anak, dan orang lanjut usia. Hal ini terutama terjadi di negara dengan pendapatan per kapita rendah dan menengah. Penyakit ISPA merupakan salah satu penyebab utama konsultasi atau rawat inap di fasilitas pelayanan kesehatan terutama pada bagian perawatan anak.'

Di Indonesia angka kejadian ISPA cukup tinggi. Berdasarkan data dari Survei Kesehatan dan Demografi Indonesia (SKDI) tahun 2012 sebanyak $5 \%$ anak usia di bawah 5 tahun di Indonesia terkena ISPA. ${ }^{2}$ Menurut survei Riset Kesehatan Dasar (Riskesdas) 2007, prevalensi ISPA ditemukan $25,5 \%$ dari seluruh penyebab yang mengakibatkan angka kesakitan pada anak usia di bawah 5 tahun, angka kematian pada anak usia di bawah 5 tahun akibat ISPA sebesar $13,2 \% .^{3}$ Infeksi saluran pernapasan akut (ISPA) masih menjadi masalah yang utama di bidang kesehatan di Provinsi Jawa Barat. Diperkirakan 429.460 anak usia di bawah 5 tahun mengalami ISPA. Salah satu kabupaten di Jawa Barat yang memiliki angka kejadian ISPA cukup tinggi adalah Kabupaten Garut, diperkirakan 26.200 anak usia di bawah 5 tahun terjangkit ISPA. ${ }^{4}$ Data dari Rumah Sakit Umum Nurhayati Garut didapatkan bahwa ISPA merupakan penyebab paling sering mengakibatkan kesakitan pada anak usia di bawah 5 tahun di bagian poli anak. ${ }^{5}$

Data dari Departemen Kesehatan Republik
Indonesia menyatakan bahwa kejadian ISPA pada anak dibawah usia 5 tahun didominasi oleh anak laki-laki. Perbandingan kejadian antara anak laki-laki dan perempuan sejak tahun 2004 sampai 2008 telah mengalami penurunan. ${ }^{6}$ Anak laki-laki lebih rentan terkena ISPA karena mempunyai aktivitas yang lebih aktif dibanding dengan anak perempuan. ${ }^{7}$ Selain itu, hal ini disebabkan oleh karena faktor hormonal karena terdapat perbedaan respons imunologis antara laki-laki dan perempuan yang mengakibatkan ISPA lebih sering kejadiannya pada anak lakilaki dibanding dengan perempuan. ${ }^{8-10}$

Anak usia 1-5 tahun lebih rentan terkena ISPA, disebabkan karena anak tersebut memiliki respons imunologis yang masih belum sempurna sehingga lebih rentan terkena ISPA. ${ }^{10,11}$ Faktor lain yang dapat mengakibatkan kejadian ISPA tinggi pada anak usia di bawah 5 tahun adalah riwayat BBLR. Anak dengan riwayat BBLR akan mempunyai imunoglobulin $\mathrm{G}$ ( $\mathrm{IgG}$ ) yang rendah $^{10}$ dan riwayat BBLR akan mengakibatkan kelainan pada saluran pernapasan, baik secara permanen atau sementara, yang akan berperan pada kejadian ISPA. ${ }^{12-15}$ Terdapat faktor lain yang berperan terhadap kejadian ISPA seperti tidak melakukan imunisasi yang lengkap, tidak diberikan ASI eksklusif, status gizi kurang, dan penyakit lain yang bersamaan dengan kejadian ISPA sehingga faktor ini harus dikendalikan. ${ }^{1}$

Tujuan penelitian ini untuk menganalisis hubungan jenis kelamin, usia, dan riwayat BBLR dengan kejadian ISPA pada anak usia 1-5 tahun.

\section{Metode}

Penelitian observasional ini dilakukan dengan rancangan cross sectional. Data diperoleh dari rekam medis dan kuesioner yang diisi oleh orangtua pasien anak usia 1-5 tahun yang didiagnosis ISPA dan non ISPA sebagai kontrol. Penelitian ini dilakukan di Poli Anak Rumah Sakit Umum (RSU) Nurhayati Kabupaten Garut periode 1 April-14 Juni 2014.

Kriteria inklusi pada penelitian ini adalah pasien anak usia 1-5 tahun yang didiagnosis ISPA dan non ISPA, orangtua pasien bersedia mengisi kuesioner, memiliki status imunisasi lengkap, memiliki status gizi yang normal atau lebih, dan tidak terdapat penyakit lain. Kriteria eksklusi adalah orangtua pasien yang menjawab kuesioner tidak lengkap. Variabel bebas atau variabel indipenden adalah jenis kelamin, usia, 
dan riwayat BBLR. Variabel terikat atau variabel dependen adalah status ISPA pada anak usia 1-5 tahun. Variabel terkendali adalah status imunisasi, pemberian ASI eksklusif, status gizi, dan terdapat penyakit lain. Sampel yang dipergunakan adalah total populasi. Uji statistik yang dilakukan yaitu uji chi-kuadrat.

Aspek etik pada penelitian ini menggunakan 3 (tiga) prinsip yaitu respect for persons, beneficence, non maleficence, dan justice.

\section{Hasil}

Selama periode penelitian terdapat 239 anak yang berkunjung ke Poli Anak Rumah Sakit Umum (RSU) Nurhayati Kabupaten Garut. Anak yang menderita ISPA yang sesuai dengan kriteria inklusi sebanyak 68 anak $(47,2 \%)$. Responden yang menderita penyakit selain ISPA (non ISPA) berjumlah 79, tetapi dari jumlah tersebut yang terpilih sebagai kontrol yang sesuai dengan kriteria inklusi berjumlah 76 anak (52,8\%) (Tabel 1).

Hubungan antara jenis kelamin dan kejadian ISPA pada anak usia $1-5$ tahun juga dapat dijelaskan pada Tabel 1.

Tabel 1 menunjukkan sebanyak $58 \%$ anak laki-laki menderita ISPA dan $42 \%$ non ISPA, hasil tersebut berbeda dengan anak perempuan, ditemukan $68 \%$ anak non ISPA dan $32 \%$ ISPA. Uji chi-kuadrat diperoleh nilai $\mathrm{p}=0,002$, nilai ini menunjukkan hubungan yang bermakna antara jenis kelamin dan kejadian ISPA. Anak laki-laki lebih berisiko terkena ISPA sebanyak 1,839 kali bila dibandingkan dengan perempuan. Nilai koefisien phi sebesar 0,263, menyatakan bahwa jenis kelamin mempunyai korelasi derajat lemah dengan kejadian ISPA.

Hubungan antara usia dan kejadian ISPA pada anak usia $1-5$ tahun dapat dijelaskan pada Tabel 2. Tabel 2 menunjukkan sebanyak $58 \%$ anak usia 1-3 tahun menderita ISPA dan $42 \%$ anak non ISPA, hasil tersebut berbeda dengan anak $3-5$ tahun, terdapat $67 \%$ menderita non ISPA dan $33 \%$ menderita ISPA. Uji chi-kuadrat didapatkan $\mathrm{p}=0,003$, hal ini menunjukkan terdapat hubungan yang bermakna antara usia dan kejadian ISPA. Anak usia 1-3 tahun lebih berisiko 1,77 kali terkena ISPA dibandingkan dengan anak usia 3 sampai 5 tahun. Berdasarkan nilai koefisien $\mathrm{phi}=0,248$, menunjukkan usia memiliki korelasi lemah dengan kejadian ISPA.

Hubungan antara berat badan lahir dan kejadian ISPA pada anak usia 1-5 tahun dapat dijelaskan pada Tabel 3. Ditemukan sebanyak $52,9 \%$ anak yang memiliki riwayat berat lahir yang normal menderita non ISPA dan sebanyak $47,1 \%$ menderita ISPA. Berdasarkan uji chikuadrat diperoleh $\mathrm{p}=0,910$, menunjukkan tidak terdapat hubungan bermakna antara riwayat BBLR dan kejadian ISPA. Riwayat BBLR bukan faktor risiko ISPA karena walaupun nilai RP lebih dari 1 namun nilai IK mencakup nilai 1. Berdasarkan nilai koefisien phi $=0,009$, berarti riwayat BBLR memiliki korelasi sangat lemah dengan kejadian ISPA.

\section{Pembahasan}

Berdasarkan hasil analisis statistik didapatkan hubungan bermakna jenis kelamin dan usia dengan kejadian ISPA pada anak usia 1-5 tahun, dan tidak terdapat hubungan bermakna antara riwayat BBLR dan kejadian ISPA. Mekanisme hubungan antara jenis kelamin dan kejadian ISPA dapat disebabkan oleh faktor aktivitas anak laki-laki yang lebih aktif bila bila dibanding dengan anak perempuan sehingga memungkinkan anak laki-laki lebih sering terpapar agen penyebab ISPA. ${ }^{7}$ Mekanisme lain yang mungkin memengaruhi adalah faktor perbedaan hormonal. Perempuan mempunyai hormon $17 \beta$-estradiol yang akan menstabilisasi dan meningkatkan reaksi imunitas bila terjadi

Tabel 1 Hubungan Jenis Kelamin dengan Kejadian Infeksi Saluran Pernapasan Akut (ISPA)

\begin{tabular}{|c|c|c|c|c|c|c|c|}
\hline \multirow[b]{2}{*}{ Jenis Kelamin } & \multicolumn{3}{|c|}{ Kelompok } & \multirow[b]{2}{*}{$\begin{array}{c}\text { Nilai } \\
\mathbf{p}\end{array}$} & \multirow[b]{2}{*}{$\mathbf{R P}$} & \multirow[b]{2}{*}{$95 \%$ IK } & \multirow[b]{2}{*}{ Phi } \\
\hline & ISPA & $\begin{array}{l}\text { Non } \\
\text { ISPA }\end{array}$ & Jumlah & & & & \\
\hline Laki-laki (\%) & $49(58 \%)$ & $35(42 \%)$ & $84(100 \%)$ & 0,002 & 1,839 & $1,507-6,058$ & 0,263 \\
\hline Perempuan (\%) & $19(32 \%)$ & $41(68 \%)$ & $60(100 \%)$ & & & & \\
\hline Jumlah (\%) & $68(47,2 \%)$ & $76(52,8 \%)$ & $144(100 \%)$ & & & & \\
\hline
\end{tabular}


Tabel 2 Hubungan Usia dengan Kejadian Infeksi Saluran Pernapasan Akut (ISPA)

\begin{tabular}{|c|c|c|c|c|c|c|c|}
\hline \multirow[b]{2}{*}{ Usia (Tahun) } & \multicolumn{3}{|c|}{ Kelompok } & \multirow[b]{2}{*}{$\begin{array}{c}\text { Nilai } \\
\mathbf{p}\end{array}$} & \multirow[b]{2}{*}{$\mathbf{R P}$} & \multirow[b]{2}{*}{$95 \%$ IK } & \multirow[b]{2}{*}{ Phi } \\
\hline & ISPA & $\begin{array}{l}\text { Non } \\
\text { ISPA }\end{array}$ & Jumlah & & & & \\
\hline $1-3$ & $48(58 \%)$ & $35(42 \%)$ & $83(100 \%)$ & 0,003 & 1,77 & $1,411-5,603$ & 0,248 \\
\hline $3-5$ & $20(33 \%)$ & $41(67 \%)$ & $61(100 \%)$ & & & & \\
\hline Jumlah & $68(47,2 \%)$ & $76(52,8 \%)$ & $144(100 \%)$ & & & & \\
\hline
\end{tabular}

infeksi, yakni dengan mengeluarkan mediator inflamasi TNF, IL-2, IL-4, IL-6, IL-8, dan IFN- $\gamma$. Mediator tersebut sangat berguna ketika terjadi suatu respons inflamasi saat terjadi infeksi. Salah satu contohnya yaitu TNF dan interleukin yang berguna sebagai penginduksi pengeluaran vascular cell adhesion molecule-1 (VCAM-1) dan intercellullar adhesion molecule-1 (ICAM1). Adhesion molecule-1 tersebut merupakan protein yang berguna untuk proses adhesi dan transmigrasi leukosit dari intravaskular ke interstitial ketika terjadi respons inflamasi. Pada laki-laki hormon testosteron mempunyai sedikit aktivitas untuk dapat menghambat pengeluaran IL-2, IL-4, IL-10, TNF, dan IFN- $\gamma$ yang akan mengganggu respons inflamasi ketika terjadi infeksi. ${ }^{8}$

Mekanisme hubungan usia dengan kejadian ISPA dapat disebabkan oleh karena mekanisme faktor imunitas yang belum terbentuk secara sempurna. Anak sebenarnya memiliki kadar sel T yang cukup tinggi, namun sel $\mathrm{T}$ tersebut masih berbentuk naif. Sel $\mathrm{T}$ yang berbentuk naif tersebut tidak akan berespons terhadap suatu paparan antigen tertentu, salah satunya adalah paparan antigen bila terjadi infeksi, ditambah paparan agen infeksi yang paling sering pada anak yaitu melalui saluran pernapasan. Hal inilah yang menyebabkan infeksi yang paling sering terjadi pada anak adalah infeksi saluran pernapasan akut. Mekanisme imunologi lain yang menyebabkan ISPA lebih sering pada anak terutama usia di bawah 5 tahun adalah kadar IgG yang belum optimal sehingga memungkinkan terjadi infeksi saluran pernapasan akut akibat respons imunitas yang tidak adekuat. ${ }^{11}$

Antibodi janin dibentuk pada awal minggu ke-20, lalu akan terus dibentuk sampai mencapai kadar optimal pada usia di atas 5 tahun. Pada bulan awal kelahiran, bayi memperoleh IgG dari IgG ibu. IgG tersebut akan menghilang ketika usia $6-8$ bulan postnatal dan akan meningkat secara bertahap hingga sampai mencapai kadar optimal pada usia di atas 5 tahun, terutama pada usia 7-8 tahun. Imunoglobulin G (IgG) ini merupakan salah satu antibodi yang penting untuk proteksi pada usia dini dan mencegah infeksi saluran pernapasan. Bila IgG ini belum optimal mengakibatkan respons imunitas pada saluran pernapasan tidak optimal pula sehingga terjadi infeksi saluran pernapasan. ${ }^{11}$

Riwayat BBLR dengan kejadian ISPA pada penelitian ini tidak mempunyai hubungan yang bermakna. Hal ini dapat disebabkan jumlah subjek penelitian dan kontrol yang mempunyai riwayat BBLR sedikit sehingga jumlahnya tidak cukup untuk menggambarkan kejadian ISPA pada anak BBLR dan anak yang memiliki berat badan lahir normal. Hal ini sangat memengaruhi hasil penelitian ini. Alasan lain yang dapat mengakibatkan anak yang mempunyai riwayat BBLR tidak terdapat hubungan bermakna dengan kejadian ISPA pada penelitian ini yaitu faktor status gizi yang merupakan variabel

Tabel 3 Hubungan Riwayat Berat Badan Lahir Rendah dengan Kejadian Infeksi Saluran Pernapasan Akut (ISPA)

\begin{tabular}{|c|c|c|c|c|c|c|c|}
\hline \multirow{2}{*}{$\begin{array}{c}\text { Riwayat Berat } \\
\text { Badan Lahir }\end{array}$} & \multicolumn{3}{|c|}{ Kelompok } & \multirow{2}{*}{$\begin{array}{c}\text { Nilai } \\
\mathbf{p}\end{array}$} & \multirow[b]{2}{*}{$\mathbf{R P}$} & \multirow[b]{2}{*}{$95 \%$ IK } & \multirow[b]{2}{*}{ Phi } \\
\hline & ISPA & $\begin{array}{l}\text { Non } \\
\text { ISPA }\end{array}$ & Jumlah & & & & \\
\hline BBLR & 2 & 2 & 4 & 0,910 & 1,06 & $0,154-8,185$ & 0,009 \\
\hline Non BBLR & $66(47,1 \%)$ & $74(52,9 \%)$ & $140(100 \%)$ & & & & \\
\hline Jumlah & $68(47,2 \%)$ & $76(52,8 \%)$ & $144(100 \%)$ & & & & \\
\hline
\end{tabular}


perancu. Status gizi normal dan lebih yang menjadi subjek dan kontrol pada penelitian ini, sedangkan riwayat BBLR memengaruhi kejadian ISPA sehingga status gizi anak usia 1-5 tahun menjadi kurang atau sangat kurang. Berdasarkan kurva Dancis rata-rata anak yang memiliki riwayat BBLR sulit mencapai berat badan ideal pada anak yang mempunyai riwayat BBLR bila dibanding dengan anak yang memiliki berat badan lahir normal. Berat badan secara umum digunakan untuk mengukur status gizi. Bila status gizi kurang atau sangat kurang secara langsung akan mengakibatkan hambatan reaksi imunologis sehingga pasien rentan terkena infeksi terutama infeksi saluran pernapasan. Saluran pernapasan merupakan jalan masuk paling sering suatu agen infeksi yang akhirnya dapat mengakibatkan ISPA. ${ }^{14}$ Mekanisme ini tidak terjadi pada penelitian ini karena anak yang memiliki status gizi yang kurang atau sangat kurang merupakan variabel perancu dan tidak dimasukkan sebagai subjek dan kontrol penelitian ini.

\section{Simpulan}

Terdapat hubungan jenis kelamin dan usia dengan ISPA pada anak usia 1-5 tahun dan tidak terdapat hubungan antara riwayat BBLR dan kejadian ISPA.

\section{Ucapan Terima Kasih}

Ucapan terima kasih penulis sampaikan kepada pimpinan Fakultas Kedokteran (FK) Universitas Islam Bandung dan Rumah Sakit Umum (RSU) Nurhayati Kabupaten Garut.

\section{Daftar Pustaka}

1. World Health Organization. Pedoman interim WHO. Pedoman pencegahan dan pengendalian infeksi saluran pernapasan akut (ISPA) yang cenderung menjadi epidemi dan pandemi di fasilitas pelayanan kesehatan. 2007 [diunduh 7 Desember 2013]. Tersedia dari: http://apps.who.int/ iris/bitstream/10665/69707/14/WHO_ CDS_EPR_2007.6_ind.pdf

2. Badan Pusat Statistik Kemenkes. Survei Kesehatan dan Demografi Indonesia. 2012 [diunduh 25 Desember 2013]. Tersedia dari: https://www.google.com/url?sa=t\&rct=j\& $\mathrm{q}=\&$ esrc $=\mathrm{s} \&$ source $=$ web\& $\mathrm{cd}=1 \& \mathrm{cad}=\mathrm{rja} \& \mathrm{u}$ act $=8 \&$ ved $=0$ CCcQFjAA\&url $=$ http\%3A\%2 F\%2Ffkm.unej.ac.id\%2Fpublikasi\%2Flainlain\%2Fcategory\%2F8-laporan\%3Fdow nload\%3D46\%3Alaporan-pendahuluanremaja-sdki-2012\&ei=gmEwU8qlK8T_rQfl 54DYAg\&usg=AFQjCNF4QrBnbHvnh $4 \mathrm{MQ}$ 3Rq1LoXI8IR_mQ\&sig2=Cc6AjlE8BXU9k yisIBarMQ\&bvm=bv.62922401,d.bmk.

3. BPPK Departemen Kesehatan Republik Indonesia. Riset Kesehatan Dasar (RISKESDAS). 2007 [diunduh 7 Desember 2013]. Tersedia dari: http:// www.k4health.org/sites/default/files/ laporanNasional\%20Riskesdas\%202007. pdf

4. Departemen Kesehatan Republik Indonesia. Profil Kesehatan Jawa Barat. 2012 [diunduh 7 Desember 2013]. Tersedia dari: http://www.depkes.go.id/ index.php?vw=2\&pg = ProfilKesehatan Kabupaten

5. RSU Nurhayati. Penyakit tersering pada anak di bawah 5 tahun. Garut: RSU Nurhayati; 2014.

6. Kementrian Kesehatan RI. Buletin Jendela Epidemiologi Pneumonia Balita. 2008 [diunduh 10 Desember 2013]. Tersedia dari: http://www.depkes.go.id/downloads/ publikasi/buletin / B ULETIN\% 20 PNEUMONIA.pdf

7. Nur Hidayat. Faktor-faktor yang berhubungan dengan kejadian penyakit ISPA pada balita di Kelurahan Paie nan Tigo Kecamatan Koto Tangah Kota Padang. 2014 [diunduh 7 Desember 2013]. Tersedia dari: http://repository.usu.ac.id/ bitstream/123456789/14580/1/011000210. pdf

8. Falagas ME. Sex differences in the incidence and severity of respiratory tract infections. Boston MA, USA: Tufts University School of Medicine; 2007.

9. Haryani S. Faktor-faktor yang berhubungan dengan kejadian ISPA pada balita di wilayah kerja Puskesmas DTP Jamanis Kabupaten Tasikmalaya 2010 [diunduh 3 Desember 2013]. Tersedia dari: http://www.scribd. com/doc/200048125/9Hariyani-StikesRespati-TSM-18-PDF

10. Yadav KY, Pan A, Gupta SK, Shah GS, Baral DDPP. Risk factors for acute respiratory infections in hospitalized under five 
children in Central Nepal. 2013 [diunduh 1 Desember 2013]. Tersedia dari: http:// www. nepjol.info/index.php/JNPS/article/ viewFile $/ 7358 / 6650$

11. Baratawidjaja KG, Rengganis I. imunologi dasar FK UI. Edisi ke-8. Jakarta: FK UI; 2009.

12. Kliegman RM, Behrman RE, Jenson HB, Stanton BF, penyunting. Nelson textbook of pediatrics. Edisi ke-18. Philadelphia: Saunders Elsevier; 2007.

13. Sadono W, Sidhartani ZM. Berat badan lahir rendah sebagai salah satu faktor resiko infeksi saluran pernafasan akut pada bayi (studi kasus di Blora). Universitas Diponegoro [diunduh 7 Desember 2013]. Tersedia dari: http://eprints.undip. ac.id/5249/1/Sadono_Wiwoho.pdf

14. Kliegman RM, Behrman RE, Arvin AM, penyunting. Nelson textbook of pediatrics. Edisi ke-15. Philadelphia: Saunders Company; 2003.

15. Stewart JKHM, Nair H. Risk factors for severe acute lower respiratory infections in children - a systematic review and metaanalysis. Croatian Med J. 2013. Tersedia dari: http://www.ncbi.nlm.nih.gov/pmc/ articles/PMC3641871. 